\title{
Rival demands sink genome alliance plans
}

London

Secret talks between rival teams racing to complete the sequencing of the human genome have failed, dashing hopes of collaboration and leaving a trail of recriminations.

The two teams - the publicly funded Human Genome Project (HGP) and the private company Celera - had been discussing forming an alliance to pool their resources, but, as in a previous attempt to collaborate (see Nature 397, 93; 1999), they stumbled primarily over the issue of public access to data.

Although the HGP is opposed in principle to any kind of privileged access to data, it had offered a compromise allowing Celera some rights to any data generated as a collaboration for twelve months, in order to speed up completion of the sequence.

Celera's compromise was that the consensus genome could be released publicly at the time of completion, but only on the condition that the data could not be used to compete with Celera's position as a database provider for three to five years. All researchers would have unrestricted use of primary data, says a Celera spokesman, but data merged from the HGP and Celera projects and assembled by Celera "should not be given to those competing with us in the database business for a period of time".

Both sides are now bristling with anger. In frustration, the UK's Wellcome Trust, a major participant in the HGP, released last weekend a confidential letter sent to Celera by the HGP, numbering the issues it says were hampering talks and asking for a response before 6 March 2000.

The letter - whose signatories include Francis Collins, director of the US National Human Genome Research Institute and Harold Varmus, director of the US National Institutes of Health - outlines the HGP's concerns about Celera's desire to have its commercial rights extended to research applications. These include the construction of genome chips, large primer sets, or applications to proteomics and analysis of regulatory sequences.

"Our position is that we would do nothing in collaboration that would affect our ability to develop the intellectual property on our discoveries," says Paul Gilman, director of policy planning at Celera.

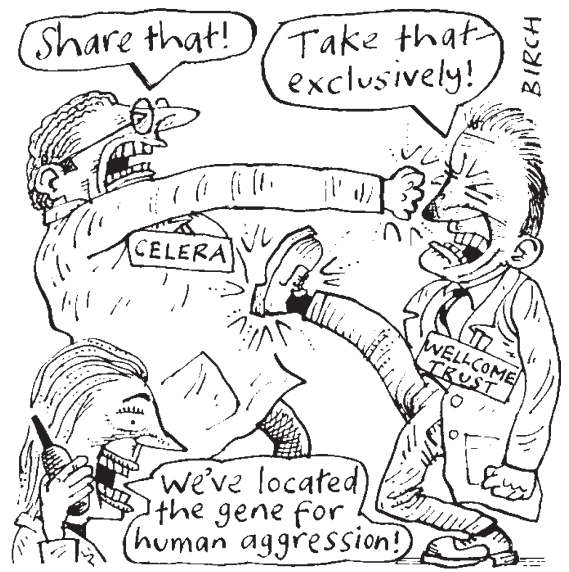

The letter says that the HGP is troubled by what it perceives as Celera's intention to publish under its own name merged data in a peer-reviewed journal. "We would give appropriate acknowledgement or credit for [HGP scientists'] contributions - if they chose not to collaborate," says Gilman.

Michael Morgan, chief executive of the Wellcome Trust's genome campus, says he felt forced to release the letter in advance of the response deadline because the Trust had been "frustrated" by Celera's lack of response. "Negotiations seemed to be going nowhere," he says. At the same time, Celera was making optimistic statements in public, expressing hope that a collaboration would get off the ground, says Morgan.

Celera counters that the early release of the letter was neither ethical nor "in the spirit of co-operation". This week Venter told The Washington Post that releasing the letter was "a low-life thing to do". Meanwhile, John Sulston, director of the Sanger sequencing centre, told the BBC Today programme that Celera's taking public data and selling it with their own amounted to something of a "con-job".

Hopes are now dwindling that the groups could work together. Morgan says this is not the end of the idea but warns that the possibility for collaboration is dwindling. "The train is rapidly leaving the station," he says.

Gilman declined to say where the collaboration stands "until we have heard directly from the National Institutes of Health or the Wellcome Trust".

Natasha Loder

\section{Biology back issues free as publishers walk HighWire}

Paris

Eighty-three life sciences journals will make their back issues - representing more than 137,000 articles - free on the web through High Wire Press.

HighWire Press is a not-for-profit outfit set up in 1995 by Stanford University Libraries and Academic Information Resources to help universities and societies to publish on the web at low cost.

This new agreement with the 83 journals makes HighWire the world's second-largest scientific repository, after the US space agency NASA's Astrophysics Data System. It already dwarfs the nascent PubMed Central (PMC) initiative that has been set up by the US National Institutes of Health - whose goal is to create a free global website for the entire life sciences literature (see Nature 401, 6 \& 626; 1999).

PMC went live last month, but has so far attracted only a handful of publishers, many of whose back issues are also available from
HighWire, such as Molecular Biology of the Cell and Proceedings of the National Academy of Sciences (PNAS).

Most journals taking part in the HighWire scheme will make their content free one or two years after print publication (see http:// highwire.stanford.edu/lists/freeart.dtl) and frequently also on a trial basis. But PNAS is making its content freely available one month after print publication, and Molecular Biology of the Cell after two.

David Lipman, director of the National Center for Biotechnology Information at the NIH and one of the main architects of PMC, puts a brave face on this situation.

The HighWire initiative is "a great thing", he says. "It shows in principle that journals are willing to make back content free and therefore should be willing to take part in PMC.

"Our goal is to provide free access for all life sciences. HighWire can only do it for journals that are paying them."
But some editors are already questioning the need for PMC. Ira Mellman, editor-inchief of The Journal of Cell Biology, which is making its back issues free on HighWire after 18 months, says: "Allowing journals and publishers to select their own host sites makes more sense than trying to enforce a common solution on all.”

Another journal editor adds: "Virtually everything they have proposed in this regard has been developed by Highwire and other commercial sites. Free access is already provided to literally anyone at an academic or commercial institution."

HighWire's publisher, Michael Keller, says he intends "to expand the coverage of our disciplines".

Momentum for making past content freely available is growing, Keller claims. "The success of the free back issues effort will be so considerable that many publishers will want to go in that direction to achieve that social goal," he says.

Declan Butler 